Journal of Bangladesh Academy of Sciences, Vol. 37, No. 1, 115-120, 2013

- Short communication

\title{
A MOLECULAR INSIGHT OF SOME PROBIOTIC BACTERIA TO ADDRESS THEIR ANTAGONISTIC ACTIVITY AGAINST PATHOGENIC VIBRIOS CAUSING SHRIMP MORTALITY
}

\author{
TASMIA FARZANA, SHAFIQUR RAHMAN, M. NIAMUL NASER ${ }^{1}$ AND \\ MUHAMMAD MANJURUL KARIM* \\ Department of Microbiology, University of Dhaka, Dhaka 1000, Bangladesh
}

\begin{abstract}
The molecular basis of antagonistic activity of a number of probiotic bacteria was analyzed using plasmid curing method. Earlier, six bacteria having potential probiotic activity under laboratory conditions were screened from 96 isolates which were obtained from shrimp rearing environment from south-west coastal region of Bangladesh. Among the isolated probionts, five were subjected to plasmid curing method and three were found to harbor plasmids, as was revealed in an agarose gel electrophoresis. Curing of these plasmids demonstrated that the bacteria lost its antagonistic activity, indicating the activity could be plasmid-borne. The antagonistic activities of the rest two isolates however, were not plasmid-oriented as no plasmid was recovered from them.
\end{abstract}

Key words: Probiotic bacteria, Antibiotic, Vibrios, Plasmid

Shrimp aquaculture production in much of the world is handicapped by disease, particularly caused by luminous Vibrio spp. and/or viruses. A study conducted on penaeid shrimp hatcheries of Cox's Bazar, Bangladesh identified a good number of pathogenic vibrios in the rearing waters (Rahman et al. 2010). Interestingly enough, pathogenic vibrios have been reported to be liberated, once imported Artemia cysts of commercial brands are hatched for feeding shrimp in hatchery operations of Bangladesh (Fahmi et al. 2010). Antibiotics, which have been used in large quantities to inhibit these bugs, are in many cases ineffective and additionally, added a burden of generating antibiotic-resistant microorganisms if used in an uncontrolled fashion (Ama'Bile et al. 1995). The thought for avoidance of antibiotics use has led to several alternative approaches for disease prevention, and the use of nonpathogenic bacteria as probiotic biocontrol agents (Westerdahl et al. 1991, Smith and Davey 1993, Austin et al. 1995, Verschuere et al. 2000) appeared as highly successful. Generally probiotics can be defined as a consortium of microbial cells or its components that have a beneficial effect on the health of host (Fuller 1989). The range of probiotics examined for use in

Corresponding author: <manjur@univdhaka.edu>.

${ }^{1}$ Department of Zoology, University of Dhaka, Dhaka-1000, Bangladesh. 
aquaculture encompasses both Gram-negative and Gram-positive bacteria, bacteriophages, yeasts and unicellular algae (Irianto and Austin 2002). A Pseudomonas sp. for example, isolated from a brackish water lagoon showed significant probiotic activity against a number of shrimp pathogenic vibrios, while its safety in the shrimp and mammalian system was found satisfactory (Vijayan et al. 2006). The losses of shrimp production due to luminous vibriosis were found catastrophic and could not be controlled even after use of antibiotics. The use of probiotic bacteria, afterwards produced no disease and the shrimp survival was recorded satisfactory (Moriarty 1998).

Given the philosophy of designing the products and processes that minimize the use and generation of hazardous chemicals, probiotic technology could be considered as an approach to green chemistry. It aims to avoid problems before they happen. In this study, attempts were made to address the molecular mechanism of probiotic activity of five probiotic bacteria, previously isolated from shrimp rearing environment (Rahman et al. 2011). Such an analysis is essential for the understanding and implementation of probiotic technology here in Bangladesh.

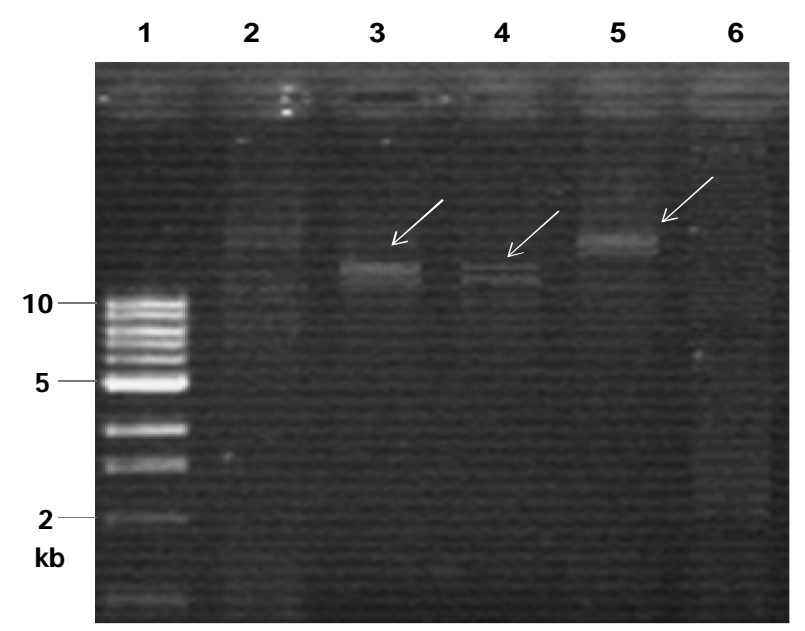

Fig. 1. Electrophoresis on a $0.5 \%$ agarose gel after plasmid extraction. While lane 1 contains a $1 \mathrm{~kb}$ DNA marker, lanes 2-6 accommodate the plasmids extracted from strains 'A', 'B', 'D', 'E' and 'F', respectively. The presence of plasmids is indicated with arrows.

This study was conducted with five putative probiotic bacteria, hereafter designated as, 'A' (for SCT10P2), 'B' (for SCS192N), 'D' (for SCT012C), 'E' (for SCT015C) and 'F' (for SCT013C) (Rahman et al. 2011). These bacteria were isolated using different culture media by observing zone of inhibition against pathogenic vibrios (Rahman et al. 2010). The probiotic potential was initially examined in agar diffusion assay, and the observation was finalized with the concatenation of screening including characterization, 
ensuring mammalian safety, and cytotoxicity test; and presumptive identification by microscopic observation and biochemical properties (Rahman et al. 2009, 2011). In this study, these five isolates were examined for presence of plasmid, followed by their curing (removal) if present, in order to correlate their involvement in bringing about antagonistic activity against the pathogenic organisms.

Plasmid extraction was accomplished using pure link Quick plasmid Miniprep kit (Invitrogen, Life Technologies Corporation, USA) following the manufacturer's instruction. Extracted plasmids were visualized by electrophoresis on a $0.5 \%$ agarose gel followed by staining with ethidium bromide (Et-Br). Distinct bands for plasmids, having $>10 \mathrm{~kb}$ sizes were observed in gel, but only for isolates 'B', 'D', and ' $E$ '; while 'A' and 'F' did not produce the same (Fig. 1).

Curing of plasmid was performed by the method of Tomeda et al. (1968). An overnight culture of each test organism in Luria Bertani (LB) broth was diluted up to a concentration of $10^{4}$ cells $/ \mathrm{ml}$. From this diluted culture, $0.5 \mathrm{ml}$ was added in to $4.5 \mathrm{ml} \mathrm{LB}$ containing curing agent, $\mathrm{Et}-\mathrm{Br}$ at concentrations of 75,100 and $125 \mu \mathrm{g} / \mathrm{ml}$, to get a bacterial population of $10^{3}$ cells $/ \mathrm{ml}$. The cultures were then incubated at $37^{\circ} \mathrm{C}$ in an orbital shaker at $150 \mathrm{rpm}$ for 48 hours and subsequently sub-cultured in LB agar medium and incubated overnight at $37^{\circ} \mathrm{C}$ with a view to obtaining bacterial colonies lacking plasmids. To score this type of cells, individual colony was selected and inoculated into $2 \mathrm{ml} \mathrm{LB}$ broth medium for an overnight incubation at $37^{\circ} \mathrm{C}$. Plasmid miniprep from $1 \mathrm{ml}$ broth of one-day-old culture was done to confirm that the cells lost their plasmids, as revealed by an agarose gel electrophoresis.

Antagonism assay was done by well diffusion assay on Mueller Hinton Agar (MHA) medium (Bauer et al. 1966, Vijayan et al. 2006) for the probiont before and after curing plasmid to compare their antagonistic activity against the target pathogen Vibrio harveyi. After 3-day incubation at $30^{\circ} \mathrm{C}$, the culture supernatant of the probiotic bacteria with or without plasmid-bearing condition was collected and added into wells in MHA medium that was previously swabbed with the target organism. The zone of inhibition was observed in the following day. While the wild-type strains produced zones of inhibition against the pathogenic vibrio, the same strains produced gradually decreased sizes of zones of inhibition around the wells with the treatment of increasing concentration of Et-Br (Panel A, Fig. 2), and this size was found zero when the Et-Br concentration was $125 \mu \mathrm{g} / \mathrm{ml}$ (Panel B, Fig. 2). This observation clearly indicates that the strains B, D and E owe their probiotic potential to the plasmids harbored inside, removal of which eventually abolish this potential completely. 
A

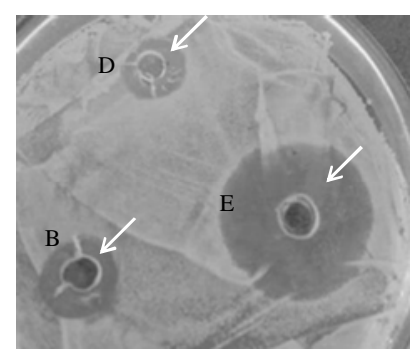

(1)

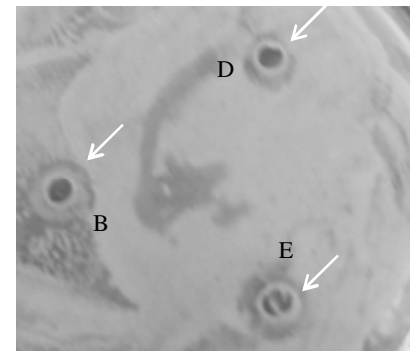

(3)

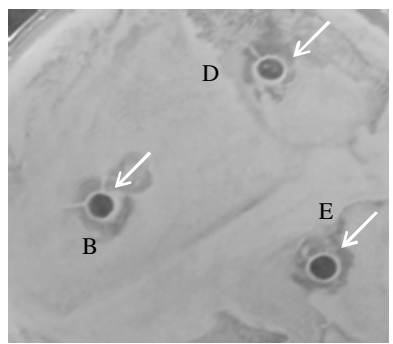

(2)

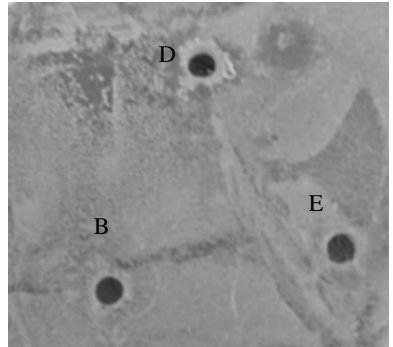

(4)

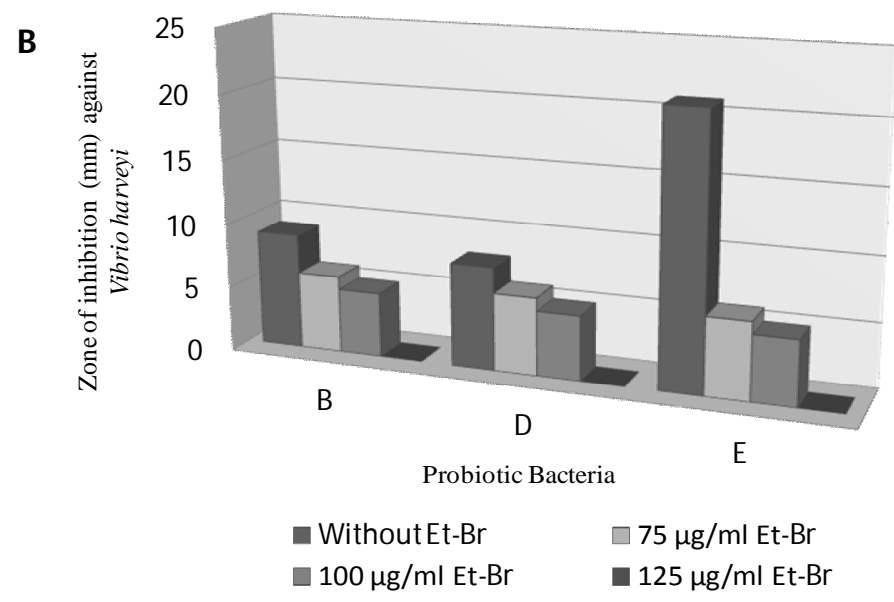

Fig. 2. Well diffusion assay produces zones of inhibition, marked with arrows for the growth of Vibrio harveyi around the wells, containing cell-free supernatant of probiotic strains, 'B', 'D' and 'E' as indicated in the Fig. This was done before (plate 1) and after plasmid curing assay with Et-Br at its 75 (plate 2), 100 (plate 3) and 125 (plate 4) $\mu \mathrm{g} / \mathrm{ml}$ concentrations (Panel A). The bar graph illustrates the zones of inhibition produced against the growth of $V$. harveyi in response to the probiotic bacterial strains: B, D and E. Curing with 75, 100 and $125 \mu \mathrm{g} / \mathrm{ml}$ concentrations of Et-Br show the gradual decrease of the zones of inhibition (Panel B).

The application of probiotics is now becoming the emerging therapy; alternative to antibiotics. This study identified three potent probiotic strains whose probiotic potentials 
against vibrio pathogens were contributed by the plasmids they harbored in cytosol. From experience, it was revealed that the environmental strains tend to shed their acquired potential, e.g. probiotic activity, upon prolonged storage in laboratory conditions. Hence, the long-term effectiveness of a probiotic isolate from the natural environment remains a tricky question. If the plasmids contributing probiotic potential could be isolated, and their effectiveness could be verified upon transformation into competent cells of laboratory strains, a smart approach would be to construct a plasmid bank conferring probiotic activity against a selective group of organisms. This will enable to prepare bacterial cells upon transformed with the plasmid conferring probiotic potential, and hence could be delivered in sites in need at any given time. The current concern is to build up such a plasmid bank, collected from environmentally isolated probiotic strains that could be readily dispensable upon requirement.

\section{REFERENCES}

Ama'Bile-Cuevas, C.F., M. Ga'rdenas-Garcia' and M. Ludgar. 1995. Antibiotic resistance. Am. Sci. 83: 320-329.

Austin, B., L. F. Stuckey, P. A. W. Robertson, I. Effendi and D. R. W. Griffith. 1995. A probiotic strain of Vibrio alginolyticus effective in reducing diseases caused by Aeromonas salmonicida, Vibrio anguillarum and Vibrio ordalii. J. Fish Dis. 18: 93-96.

Bauer, A.W., W. M. Kirby, J. C. Sherris and M. Turck. 1966. Antibiotic susceptibility testing by a standardized single disc method. Am. J. Clin. Pathol. 45: 493-496.

Fahmi, T., M. M. Karim, S. Rahman, M. N. Naser and S. N. Khan. 2010. Abundance and community structure of bacteria associated with artemia cysts commonly used in shrimp hatchery of Bangladesh. Bangladesh J. Zool. 38(1): 41-49.

Fuller, R. 1989. Probiotics in man and animals : A review. J. App. Bacteriol. 66: 365-378.

Irianto, A. and B. Austin. 2002. Review probiotics in aquaculture. J. Fish Dis. 25: 633.

Moriarty, D. J. W. 1998. Control of luminous Vibrio species in penaeid aquaculture ponds. Aquaculture 164: 351-358.

Rahman, S., S. N. Khan, M. N. Naser and M. M. Karim. 2009. Application of probiotic bacteria : A novel approach towards ensuring food safety in shrimp aquaculture. J. Bangladesh Acad. Sci. 33(1): 139-144.

Rahman, S., S. N. Khan, M. N. Naser and M. M. Karim. 2010. Isolation of Vibrio spp. from penaeid shrimp hatchery and coastal waters of Cox's Bazar, Bangladesh. Asian J. Exp. Bio. Sci. 1(2): 288-293.

Rahman, S., S. N. Khan, M. N. Naser and M. M. Karim. 2011. Safety issues of isolated probiotic natured bacteria from Bangladesh coastal waters for controlling shrimp diseases. J. Sci. Res. 3 (3): 659-668

Smith, P. and S. Davey. 1993. Evidence for the competitive exclusion of Aeromonas salmonicida from fish with stress-inducible furunculosis by a fluorescent pseudomonad. J. Fish Dis. 16: 521-524.

Tomeda, M., M. Inuzuka, N. Kubo and S. Nakamura. 1968. Effective elimination of drug resistance in sex factors in Escherichia coli by sodium dodecyl sulfate. J. Bacteriol. 95: 1078-1089.

Verschuere, L., G. Rombaut, P. Sorgeloos and W. Verstraete. 2000. Probiotic bacteria as biological control agents in aquaculture. Microb. Mol. Biol. Rev. 64(4): 655-671. 
Vijayan, K. K., I. S. B. Singh, N. S. Jayaprakash, S. V. Alavandi, S. S. Pai, R. Preetha, J. J. S. Rajan and T. C. Santiago. 2006. A brakishwater isolate of Pseudomans PS-102, a potential antagonistic bacterium against pathogenic vibrios in penaeid and non-penaeid rearing systems. Aquaculture 251(2-4): 192-200.

Westerdahl, A., J. C. Olsson, S. Kjelleberg and P. L. Conway. 1991. Isolation and characterization of turbot (Scophthalmus maximus)-associated bacteria with inhibitory effects against Vibrio anguillarum. Appl. Environ. Microbiol. 57: 2223-2228.

(Received revised manuscript on 6 February, 2013) 